\begin{tabular}{r|l|l|l}
$\begin{array}{c}\text { Case Reports in } \\
\text { Gastroenterology }\end{array}$ & $\begin{array}{l}\text { Case Rep Gastroenterol 2010;4:393-396 } \\
\text { DOl: 10.1159/000321001 }\end{array}$ & $\begin{array}{l}\text { Published online: } \\
\text { September 20, 2010 }\end{array}$ & $\begin{array}{l}\text { O 2010 S. Karger AG, Basel } \\
\text { ISSN 1662-0631 } \\
\text { www.karger.com/crg }\end{array}$ \\
\hline
\end{tabular}

This is an Open Access article licensed under the terms of the Creative Commons AttributionNonCommercial-NoDerivs 3.0 License (www.karger.com/OA-license), applicable to the online version of the article only. Distribution for non-commercial purposes only.

\title{
Endoscopic Removal of an Unusual Foreign Body Causing Gastrointestinal Bleeding
}

\author{
A. Karaman E. Torun M. Çelikbilek S. Gürsoy \\ Ö. Özbakir
}

Department of Gastroenterology, Erciyes University Faculty of Medicine, Kayseri, Turkey

\section{Key Words}

Foerign body ingestion · Hair comb ingestion · Gastrointestinal bleeding

\begin{abstract}
Foreign body ingestion is a condition more common in the pediatric population than in adults. In adults, although foreign body ingestion can be well tolerated, approximately $10-20 \%$ of patients require endoscopic intervention. Delayed diagnosis and unremoved foreign bodies can cause serious and fatal complications including perforation, fistula and gastrointestinal bleeding. Here we report a patient with bleeding duodenal ulcer thought to be initiated by a large foreign body.
\end{abstract}

\section{Introduction}

Ingestion of foreign bodies is a common clinical problem. Difficulties can often occur in both diagnostic and management protocols. Though in adults foreign body ingestion can be well tolerated, delayed diagnosis and unremoved foreign bodies can cause serious and fatal complications including perforation, fistula and gastrointestinal bleeding [1]. In this paper we report a patient with bleeding after swallowing a large foreign body.

\section{Case Report}

A 65-year-old man with coronary artery disease and atrial fibrillation was admitted to our department for evaluation of hematemesis, melena and abdominal pain. Physical examination revealed abdominal tenderness. He was pale and hypotensive $(90 / 55 \mathrm{~mm} \mathrm{Hg})$, with a heart rate of $108 \mathrm{bpm}$. All laboratory values were within normal range, except for a low level of hemoglobin $(8.9 \mathrm{~g} / \mathrm{dl})$. An esophagogastroduodenoscopy was performed after erythrocyte suspension transfusion. Endoscopic examination revealed a $13 \mathrm{~cm}$ long and $2 \mathrm{~cm}$ wide hair comb in the gastric lumen (fig. 1). In addition a deformed pylorus and a Forrest $2 \mathrm{c}$ ulcer 5-6 $\mathrm{mm}$ in diameter in the duodenal bulbi were detected (fig. 2). A foreign body protector hood was used for protecting the esophagus and the comb was 


\begin{tabular}{r|l|l|l} 
Case Reports in & $\begin{array}{l}\text { Case Rep Gastroenterol 2010;4:393-396 } \\
\text { DOl: 10.1159/000321001 }\end{array}$ & $\begin{array}{l}\text { Published online: } \\
\text { September 20, 2010 }\end{array}$ & $\begin{array}{l}\odot \text { ISSN 1662-0631 } \\
\text { www.karger.com/crg }\end{array}$ \\
\hline
\end{tabular}

grasped with a snare and carefully removed (fig. 3). Control endoscopy revealed no complication after the procedure. Chronic irritation of the duodenal bulbi by the comb was thought to be the cause of ulcer and gastrointestinal hemorrhages. On questioning, the patient did not remember how or when he had swallowed the hair comb. The patient was discharged from hospital two days after admission without any complication.

\section{Discussion}

Swallowing of foreign bodies remains a common problem with intervention difficulties. Approximately $80 \%$ of cases with accidentally foreign body aspiration occur in children [1]. In adults, ingestion of foreign bodies involuntarily occurs in the elderly population with cerebrovascular diseases, patients with drug and alcohol dependence, and also intentionally in psychiatric patients and prisoners. In the general population, $80-90 \%$ of foreign bodies will pass spontaneously. However, endoscopic intervention is required in $10-20 \%$ of patients with less than $1 \%$ of patients requiring surgery [2]. Foreign bodies may cause serious complications such as impaction, obstruction, or perforation of the digestive or respiratory tracts. Swallowed foreign bodies can impact at the anatomical narrowing areas like cricopharyngeus, lower esophageal sphincter, pylorus, ileocaecal valve and anus. Foreign bodies greater than $2-2.5 \mathrm{~cm}$ in length usually cannot enter the pylorus [3].

In our patient, we think that the comb's short side was passed through the pylorus and returned back to the antrum by the gastric peristalsis and caused the mucosal damage of the duodenal bulbi and pylorus. Ulcer bleeding occurred by chronic mucosal damage. Although it is well known that foreign bodies can cause gastrointestinal bleeding, there is no report of such a foreign body in the literature. This is the first case of comb ingenstion in the literature, whether it caused bleeding or not. Of course medication for coronary artery disease and atrial fibrillation may have caused duodenal ulcer and bleeding in this patient, but the bleeding did not continue after removal of the comb although his medications were not stopped.

In patients with gastrointestinal bleeding, especially in the elderly population, foreign bodies should also be kept in mind. 


\begin{tabular}{r|l|l|l}
$\begin{array}{r}\text { Case Reports in } \\
\text { Gastruanteriology }\end{array}$ & $\begin{array}{l}\text { Case Rep Gastroenterol 2010;4:393-396 } \\
\text { DOI: 10.1159/000321001 }\end{array}$ & $\begin{array}{l}\text { Published online: } \\
\text { September 20, 2010 }\end{array}$ & $\begin{array}{l}\text { O 2010 S. Karger AG, Basel } \\
\text { ISSN 1662-0631 } \\
\text { www.karger.com/crg }\end{array}$ \\
\hline
\end{tabular}

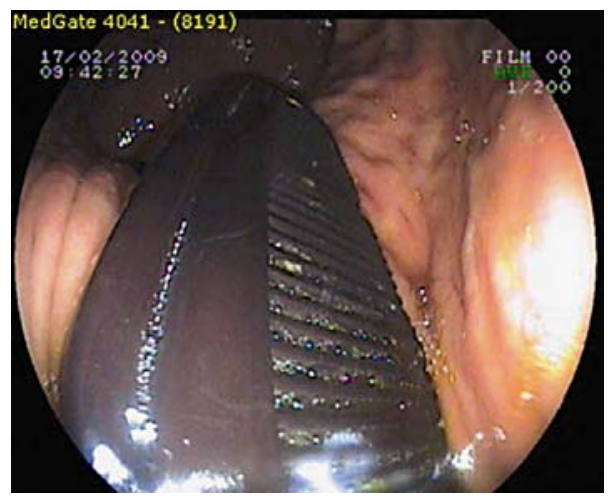

Fig. 1. Comb in the gastric lumen.

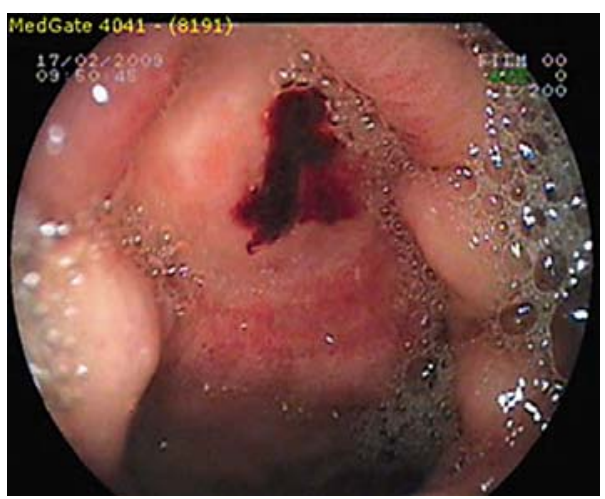

Fig. 2. Duodenal ulcer.

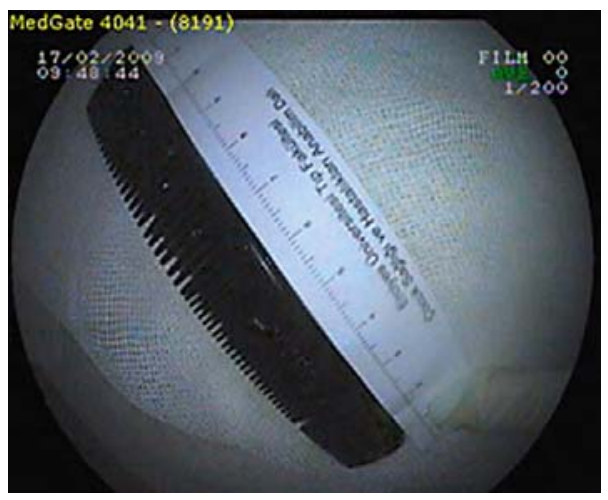

Fig. 3. Comb after removal. 


\section{References}

1 Pavlidis TE, Marakis GN, Triantafyllou A, Psarras K, Kontoulis TM, Sakantamis AK: Management of ingested foreign bodies: how justifiable is a waiting policy? Surg Laparosc Endosc Percutan Tech 2008;18:286-287.

2 Barros JL, Caballero A Jr, Rueda JC, Monturiol JM: Foreign body ingestion: management of 167 cases. World J Surg 1991;15:783-788.

-3 Bisharat M, O'Donnell ME, Gibson N, Mitchell M, Refsum SR, Carey PD, Spence RA, Lee J: Foreign body ingestion in prisoners - the Belfast experience. Ulster Med J 2008;77:110-114. 